\title{
Film education as a multiplicity of practices: A media-ecological perspective
}

\author{
Alejandro Bachmann* - Austrian Film Museum, Austria \\ Manuel Zahn - University of Cologne, Germany
}

\begin{abstract}
This paper explores a media-ecological perspective on film-education practice. Drawing from their own experiences of teaching film (at the Austrian Film Museum and the KurzFilmSchule, Hamburg) the authors challenge monolithic theories of film education, suggesting instead that film education practices are shaped by context, and are relational to the spaces and institutions in which they take place. While the paper takes as its core point of departure Alain Bergala's The Cinema Hypothesis, its intention is to shift the way we look at and reflect on film education from one text towards a multiplicity of practices. Finally, the essay considers the extent to which each of these regional theorizations are bound to their specific conditions of practice and the extent to which they still carry within them a shared understanding of the aims of film education.
\end{abstract}

Keywords: media ecology; film education; situated knowledge; conditions of practice

\section{Introduction}

While the last few years have seen a steady increase of practical endeavours in the realm of film education in Europe - from cinematheques, film museums and other institutions offering film workshops and projects specifically aimed at children and teenagers, to European projects bringing together various initiatives and creating networks (such as the Framework for Film Education in Europe) - there is hardly any extensive theory of film education, let alone a many-voiced discourse surrounding it.

This situation might be one of the reasons that Alain Bergala's The Cinema Hypothesis has been welcomed so gratefully, first in 2002 in France, later in its translated version in German in 2006 and a subsequent English edition in 2016. (Other translations exist, but it is the German version edited by Bettina Henzler and Winfried Pauleit that first brought the book to our attention, and the English version edited by Alejandro Bachmann that forms our frame of reference.) To say that The Cinema Hypothesis does not articulate a systematic theory is not in any way an attempt to downplay its significance. On the contrary, over the last 14 years the book has become the centre of attention for a significant number of people involved in film-education practices aiming to teach film in its own right, rather than using film as a tool for other pedagogical aims. In this way, it has done exactly what it set out to do: 'To convince those who want to hear it that such a goal is attainable, to help them in attaining it if they wish to do so, and to accept all the consequences, which truly are immense, of truly regarding cinema as an art' (Bergala, 2016: 20). 
The authors of this article have both worked extensively with The Cinema Hypothesis in a variety of contexts in Germany, Austria, Slovenia and the UK, ranging from seminars at university and workshops with children, to summer schools aimed at enabling teachers to integrate film and film education into their daily context in the classroom. While we both remain thankful for, and generally in agreement with, the ideas outlined by Bergala, we have - time and time again - come across various problems when integrating his ideas into the contexts of our own teaching. This observation is the point of departure for this article, which wants to suggest a mediaecological perspective on film education that will allow us not only to look at the teaching effort itself (and the theory behind it), but also at how far it is shaped by its context, and how far it is relational to the space it takes place in - the institution that provides the means of production.

In the following, we take into account our own practices of teaching film and position them in relation to the fundamental ideas outlined by Alain Bergala. Our aim is to shift the way we look at, and reflect on, film education away from one text towards a multiplicity of practices. This is not to suggest that Bergala's ideas fall short of practical realities, but rather to illustrate how every form of film education is embedded in, and thus influenced by, its regional context, which both limits and facilitates its specific implementation. Each of these practices, then, could be considered as theorizations, limited in their scope but rich in their specificity. Our intention is to show that there is not one theory of film education but rather a multiplicity of situated small filmeducational theorizations grounded in their respective applications. The concept of small, regional theorizations is here thought of in close proximity to Donna Haraway's theory of situated knowledge. In her seminal essay 'Situated knowledges: The science question in feminism and the privilege of partial perspective' (Haraway, 1988), she takes as a starting point the conditionality of scientific knowledge. Thus, the social situatedness, as well as the researcher's advantages derived from a certain context, are put into a relation to the research as a whole. Situated knowledge is thus always already perceived as locally limited, and can never be translated as being universal. Our intention is not to contradict Bergala's body of ideas, but rather to provide an expansion and reformulation of central terms and theoretical figures in The Cinema Hypothesis.

\section{The passeur and taste in relation to institutions}

Before reflecting upon our own practices, we here outline some of the core elements and theoretical figures that make up The Cinema Hypothesis. To do so is also to apply that specific perspective to Bergala's writing, that is, to show how his suggestions and ideas are themselves dependent on a certain context.

The fact that Bergala opens The Cinema Hypothesis with a chapter entitled 'The experience has been rewarding' is significant: Bergala's body of ideas is grounded in a certain context that he outlines himself, and which is constituted principally from his time as chief editor of the Cahiers du cinéma, an assignment he received from French Cultural Minister Jack Lang to come up with an approach to teaching cinema within the French school system, and the dominance of the DVD medium at the time, to name just a few. Bergala does not hide any of these contexts, but instead refers to them throughout The Cinema Hypothesis. He thus begins 'The experience has been rewarding' by stating: 'I consider it to be a stroke of good fortune, which comes along quite rarely in one's life, to be offered the chance, one day, to implement one's 
ideas, which stem from more than twenty years of reflection, experience, and dialogue' (Bergala, 2016: 11; emphasis added).

The concept of the passeur stands at the centre of Bergala's theory:

I want to note in passing - speaking of Daney, who 'invented' the term in this usage, referring to an agent of transmission - that this lovely word passeur is today used quite loosely, to fit any occasion. A passeur is someone who gives of himself, who accompanies his passengers in the boat or up the mountain, who takes the same risks as those temporarily in his charge (Bergala, 2016: 29).

It is important to understand what this entails: Bergala's idea of film education is not primarily based on a certain knowledge that must be passed from teacher to student through analysing a film or revealing its hidden ideological message, but rather on the notion of an individual experience that the student gains through an encounter with film as an art form, and which can be shaped and supported by the teacher: 'You might say, along these lines, that art cannot be taught, but must be encountered, experienced, transmitted by other means than the discourse of mere knowledge, and even sometimes without any discourse at all' (ibid.: 22). One cannot underestimate the role of the teacher as passeur in this context. It is the passeur, a character shaped by his own experiences with art, which is at the centre of Bergala's conception of film education. It is he or she as a subject who takes up responsibility for the films that he or she is showing, a subject that puts up his or her own passion and excitement for the object, and thus leaves the secure role of teacher as authoritarian figure justified by his or her knowledge and objective superiority.

The other term that plays a seminal role in The Cinema Hypothesis is 'taste'. This comes into play when Bergala (rightfully) criticises a film-educational approach that sets out to arm children against the powers of manipulation in their encounter with the cinematic medium:

If one is successful, with films whose artistic value is incontestable (if such a thing exists!), in reconstructing something that resembles taste, one will have accomplished more toward fighting bad or dangerous films than by trying, first, to hastily apply some partial tools of defensive criticism (Bergala, 2016: 30).

In that line of thought, it does not come as a surprise that Bergala expresses a scepticism towards institutions that in their very nature are not built upon the ideal of subjectivity, but rather establish structures that, ideally, create stability and consistency independent of the subjects working within them: 'The institution has a natural tendency to standardize, to amortize, indeed to absorb that element of risk represented by an encounter with any form of otherness, in order to reassure itself, and to reassure its agents' (ibid.: 21). The passeur, with his or her notion of taste, then embodies that very otherness that disturbs the institution (be that a school, a university or a film museum), because what he or she teaches is intrinsically bound to his or her passion as well as taste. It is this radical subjectivity that takes as the starting point of teaching the personal taste of the teacher that disturbs the order of an educational institution such as the school, which wants to teach the same knowledge to every student, an aim that is already implied in the term 'curriculum'.

While one may agree with Bergala's ideas of the passeur and 'taste', one has to ask at the same time: which practices of film education are taking place outside an institutional context? Which practices are absolutely free from any restraints and 
contexts, be that a two-hour session with children in a cinema, a lesson in school or a seminar set up by a cultural club run by a handful of enthusiasts? As we intend to show, it might be helpful to look at institutions differently: to look beyond Bergala's conception of institutions as rigid, monolithic blocks that stand in the way of teaching film passionately and destroy any form of subjectivity and the impact it can have, and rather to see the institution as something that is itself made up of contexts, practices, subjects, materials and media that collectively add up to a flexible context whose very existence facilitates and makes possible encounters with film. This seems especially relevant for the medium of film, which - unlike painting or literature - is far more dependent not only on the availability of film materials but on technological set-ups that allow these films to come to life. From this angle, the institution does not destroy subjectivity and otherness, but is entangled in the specific shapes they can take.

\section{Conditions of practice: Two case studies}

If we stick with Bergala's emphasis on the subject, on the passeur's capability to bring himself or herself into the act of teaching, with his or her passions and personal relation to film, and if at the same time we do not want to downplay the role of the institution or regard it as something standing in the way of the passeur, we could try to describe a teaching subject in its entanglement with an institution. This would allow us to describe a specific approach to film education (how film is taught, which idea of film is intended to be mediated) and, at the same time, understand the conditions of its practice and the practice itself - something we have described as small, regional theorizations above.

These conditions of its practice can range from material realities (such as the space in which film is being taught, the technical equipment available and the size of the room) to organizational matters (at what time of day film is being taught, and whether students come on their own or in a class context) and, last but not least, include the philosophy or mission of an institution, which will impact the specific form that teaching takes in a specific context. Thus, our theoretical perspective could be thought of in close proximity to a media-ecological perspective, which has seen a significant rise in impact in media studies over the last couple of years. A central paradigm of media-ecological thinking is the radical affirmation of being 'relational' rather than being 'individual'. Therefore, media-ecological thinking goes hand in hand with an understanding of the medium not as a singular entity, but as being part of a network of media-technological connections that are produced, become stable, dissolve and are transformed through the specific application in one or the other (also institutional) context. In this sense, a medium is to be understood as an infrastructure of perceptions, affect, and actions of human and non-human actors. (For a mediaecological perspective in the field of media studies, see Löffler and Sprenger, 2016.) Processes of learning and education are thus shaped by different networked media, which create different possibilities for the actors involved to perceive and to act within these processes, which is why it makes sense to speak of an environmental agency that is neither dominated solely by humans nor by technology. This form of shared subjectivity, experience and space to act is shared by a number of positions within this media-ecological line of thought, such as those of Gilles Deleuze, Felix Guattari, Erich Hörl, Bruno Latour, Brian Massumi, Jean-Luc Nancy, Gilbert Simondon and Bernhard Stiegler, which emphasize that humans only become subjects in relation to other humans, techniques and technologies (see Hörl, 2011). 
The media-ecological perspective suggested here thus expands educational theories within the field of media pedagogy, sociology and psychology in at least two dimensions: on the one hand, the social relationships between people are opened up to the role of non-human actors. On the other hand, it allows for the processes of communication and education to be thought of not only as symbolic-imaginary arrangements of perception, emotion and articulation, but also as an ongoing interplay between architectures, materials and bodies.

\section{The Austrian Film Museum}

Cinémathèques and Film Museums can be a particularly fruitful case study to understand how the teaching subject is always already embedded in a structure that influences and shapes his or her specific teaching practice, because these institutions have quite often been founded (and thus conceptualized) with the intention of being places of film education. For example, Henri Langlois, main founder and long-time president of the Cinémathèque française, not only founded the institution in 1936, but also talked about the films inside the cinema, showing excerpts that he carefully chose from his film collection; he is said to have been an extraordinary teacher of cinema (Richards and Johnson, 2017: 114). As film was for a long time (and partly still is) not considered to be part of high culture, there has been less pressure for film institutions to be presentable. Thus, quite often, they have shown a specific character, a certain otherness that is closely connected to one individual, a subject that has shaped the institution.

The Austrian Film Museum is no exception. Founded in 1964 by Peter Konlechner, a student at the Technical University of Vienna, and Peter Kubelka, an Austrian avantgarde film-maker, the Film Museum was conceptualized from the start as a place where people could come into contact with film in all of its possible shapes and forms, and where film could be shown, preserved, restored and taught. While film as an important, independent art form stood at the centre of this idea, from the start there was also an urge to show other modes of screen production, ranging from documentary and experimental cinema to ephemeral forms such as advertising, industrial film and amateur film-making. The Film Museum was intended to (and still does) show film as an art form, as a document, but also as a purely non-commercial means of personal expression or as a tool to record your summer vacation.

The centre of such a place had to be a cinema that was to be the exhibition space of the museum (a sign stating that 'All exhibitions take place on the screen' still welcomes every visitor to the Film Museum). Film was not to be exhibited through its objects and paratexts (such as the camera, a costume, the screenplay or old movie posters), but only through the projection of the film itself in an ideal setting - the cinema. To understand the importance of the cinema, it might be helpful to point out that Kubelka himself had designed an ideal cinema, which he called the 'Invisible Cinema'. Originally put into place in 1969 at New York's Anthology Film Archives (of which Kubelka was also a co-founder), it featured a completely black room with steep rows of seats (to make sure that everyone could see perfectly from every position) and a construction that separated each spectator from the other, visually and aurally, and left only a tiny free spot where people could come into contact with each other through their hands. On the one hand, this visual machine emphasizes the concentration that cinema can produce in experiencing a film, while it also hints at how little the place was meant to motivate interaction or communication between the people inside it. The 'Invisible Cinema 3' that is currently at the centre of the Film Museum still follows 
this basic principle, albeit without the construction enveloping each viewer in his or her own small cocoon.

In 1995, on the occasion of the 100th anniversary of film, Peter Kubelka also put together a cycle of films consisting of 63 programmes, which were screened each Tuesday. The title of that cycle - What is Film - once again emphasizes the didactic concept of its co-founder and - subsequently - the institution itself: the answer to the question of what film is can only be given by the films themselves, by a programme that encompasses about three hundred films that need to be seen on the cinema screen. Accordingly, Kubelka was against a publication to accompany the cycle and although giving in - stated:

I am not against teaching film (Vermittlung). I do it myself quite often, even in the context of my own works. But I do think that the Film Museum should favour those people who want to see these works in their original form and without any comments. We are currently in a situation where everything is being taught through language; it is like an epidemic. Galleries publish a book accompanying every exhibition, guided tours are offered and lectures are held. Everything is being taught. ... [Teaching art] covers up the thing itself and takes away the possibility of it speaking for itself. What we get is the illusion of understanding based on language. One can only understand music through listening, food through eating, film through film itself (present authors' translation; see Grissemann et al., 2010: 11).

What has been outlined so far could be summed up as the conditions of practice for film education at the Austrian Film Museum, its philosophy as an institution as well as its material realities. It is within these conditions that specific film education practices for 5- to 18-year-olds have been developed, one of which, the lectures within the School in the Cinema series, will be outlined in what follows, and placed in relation to these conditions, as well as to the ideas outlined in The Cinema Hypothesis. It is hoped that by putting this practice into relationship with the institutional conditions, as well as with Bergala's core ideas (which are seminal for how film education at the Austrian Film Museum is conceptualized), the shift of perspective discussed above will become visible.

The School in the Cinema series is one module within the larger programme of activities that the Austrian Film Museum has started developing since 2002. Currently the School in the Cinema series offers up to twenty events each semester, consisting of film screenings in their original format and language followed by in-depth analysis, alongside lectures on topics such as montage, mise en scène, the experience of time and space in cinema, the transition from silent film to sound film and film genres. There are also events for which the museum asks film-makers to decide for themselves how to present their work to students (called 'In the Studio with ...'), as well as question and answer sessions with film-makers after screenings. Focus on Film is the second regular module that is conceptualized each semester, according to the topic that is dealt with over the course of one semester with between one and three school classes. In the past, the museum has curated film programmes together with 8- to 12-year-olds, has delved into the specificity of analogue film-making by producing its own films on $16 \mathrm{~mm}$ and has offered an introduction to the history of documentary cinema. The third module is an annual Summer School, which offers teachers and other educators interested in teaching film a four-day seminar dealing with multiple forms of screen production and various approaches to teaching them. 
One element of the School in the Cinema is the so-called 'lectures'. They are offered to 7- to 18-year-olds, are two hours long, take place inside the Invisible Cinema and encompass topics including 'Manipulation and Cinema'. 'From Silence to Sound', 'Time Machine: Cinema and Temporal Experience' and 'Film as Rhythm'. Up to 164 people can participate, and the two hours are composed of a mixture of excerpts from films or shorter works in their entirety, and an analysis that is intended to happen in a dialogue between the passeur and the audience.

Two central aspects of Bergala's thinking inform these lectures, although these aspects require assimilation into the conditions within the Austrian Film Museum discussed above. When Bergala names one of his central concerns as being the imperative to make cinema visible as an art form, this is, in his case, closely connected to another element of his pedagogy, that is to make students think of film as an imprint of a creative process: 'Perhaps we should begin - though it won't be an easy task, pedagogically - by thinking of film not as an object, but as the final imprint of a creative process, and by thinking of cinema as art' (Bergala, 2016: 23). This approach cannot be applied directly to the understanding of film embodied by the Film Museum. In its aim to make people understand that film encompasses many different forms, the educational lectures always try to integrate industrial films, trailers or amateur films none of which are easily comprehended as the imprint of creativity, but rather as an imprint of an urge to remember, an urge to create interest or simply to document. The perspective thus has to change from trying to find the film-maker's ideas and intentions, to making young people sensitive to what they feel and think, and how they react, and how this might be brought about by the aesthetic cues and traces of the films. One should not mistake this approach for being at odds with Bergala's call for the development of a taste, however: film history is full of beautiful examples of films that were never intended to be creative but nevertheless still carry what Bergala (ibid.: 30) himself defines to be that moment when 'emotion and thought are born out of a form, a rhythm, that could not have existed but for cinema'. What is at stake here is, quite simply, a different set of conditions of practice: between that of a writer, cinephile (occasional film-maker) and magazine editor growing up in the realms of the Cahiers du cinéma, working close to people like Godard, and writing about Rossellini, and that of an institution with an understanding of film history that encompasses the great auteurs as well as ephemeral forms of film. So while the lectures at the Film Museum are trying to build a taste by making connections between works, these connections break up distinctions between that which is deemed art by the cinephile and that which is deemed worthy of attention to a museum curator.

Accordingly, the lectures at the Film Museum try to integrate two other elements of the conditions of practice discussed above: an understanding of the cinema space as a specific arena and apparatus for experiencing films, as well as a sense for the material realities of film that become relevant when being involved with an archive, and the practices of preservation and restoration. So, while watching the film and making the audience sensitive to the specific power of cinema as a means of expression is the starting point for these lectures, an effort to reflect on the specific conditions of the cinema in comparison to mobile phones or a home-cinema set-up is always part of any film-education activity.

This conviction goes hand in hand with another change of approach when it comes to drawing connections between the works. While, for Bergala, the DVD is the ultimate tool that allows for working with excerpts and for the drawing of connections between works throughout film history, the Austrian Film Museum tries to show full works, and even excerpts, in their original format: the first reel of $35 \mathrm{~mm}$ Technicolor 
film, such as Howard Hawks's Gentlemen Prefer Blondes (1953), may thus be followed by a $16 \mathrm{~mm}$ print of Len Lye's Free Radicals (1958) to initiate a sensibility for different analogue material realities, and finally may be put into dialogue with a digital excerpt from a more recent Michael Mann film such as Collateral (2004). While it is totally understandable from a cinephile's position to say that it is first and foremost important to see the films for their form and content, and thus use DVDs (which can be used in a classroom context), the Film Museum also has an interest in creating a sensitivity for material properties, as well as apparatuses and their impact on the film experience. The intention is not to fetishize the old over the new, but rather to create a sensitivity for material differences that the digital realm tends to negate. The importance of taste in Bergala's thinking could thus be said to be translated at the Film Museum to include other layers and elements of the film experience.

\section{The KurzFilmSchule, Hamburg}

As our second case study we focus upon a film education project based in Hamburg. The KurzFilmSchule Hamburg (ShortFilmSchool) could be called an institution, although its organizational shapes deviate significantly from that of a film museum. This becomes apparent when one asks for the location of the KurzFilmSchule. Unlike the Austrian Film Museum, the KurzFilmSchule has no specific location but rather a network that connects a number of film-makers with schools and specific classes. What unites the constituent parts within the network and makes them into an institution is a shared mission and the processes of bringing together a number of people, practices and media technologies in a certain way to reach a defined outcome.

The KurzFilmSchule was founded in 2004 by teachers from Hamburg and the office for culture, sports and media, as well as the Hamburg KurzFilmAgentur (Short Film Agency). Its aim is to enrich film education in schools by opening up access to artistic practices of film-making with the help of, and in collaboration with, film-makers from the region. Workshops lasting between five and ten days are held in which participants make their own short films with the support of professionals. Since 2005, the KurzFilmSchule Hamburg has produced ten to twelve of these workshops on an annual basis for a variety of different types of school and age groups. The technical equipment is provided by the KurzFilmSchule. Teachers are integrated into these film projects in order to provide the possibility for them to expand their own understanding of film. In comparison to the Film Museum, the approach is not so much focused on a repeated viewing and consideration of film in an ideal setting, but rather on making short films of all genres.

A central point of departure for the work of the KurzFilmSchule is the KurzFilmAgentur (KFA), which is part of Hamburg's film culture and is in close contact with independent film-makers from the region. This allows for a meaningful collaboration between film-makers and classes, which often lasts longer than the workshop itself. The KFA is engaged in distribution, an international short film festival and an international children's film festival, and has its own collection of film prints. The KFA thus provides a versatile and, more importantly, an agile film culture to which school classes can gain access: films that are produced in the workshops often become part of festival programmes, and it has become common for children and teenagers to curate and moderate programmes for their own age groups.

The KurzFilmSchule is a project in the original sense of the Latin word projectum, an open-ended endeavour towards the future. Film educators working for the KurzFilmSchule meet on a regular basis to discuss film-educational questions based on their experiences in the workshops. Teachers and students are actively motivated 
to provide feedback, which then goes into the development or alteration of the overall film-educational concept of the KurzFilmSchule. At the same time, these meetings provide the possibility for teachers and film-makers to reflect - on each other, on the different approaches, and on the institutional and discursive framework of their own work and that of others. The aim is not to consolidate opposing artistic and pedagogical discourses, but rather to make such differences visible and explore how they might be made productive for film education. One of the educational aims of the KurzFilmSchule is to accept the differences between these discourses and articulate them in order to make use of the different questions, ways of working and ways of thinking surrounding education.

In 2007 the KurzFilmSchule committed to working out a new educational concept in collaboration with all of its participating film educators. After a long process of viewing and discussing films made over the years, the significant differences between each of the film-makers and film education practitioners became clearly visible. Each of them had a different taste when it came to film, and had experienced different educational contexts. The biographical circumstances in which they had first encountered film were extremely diverse, as were the ways in which they conceptualized film and its significance for them. Consequently, their notions and ideas of film education, of young people and of what they already know or should learn and - most importantly how they should learn, differed immensely.

Alain Bergala's The Cinema Hypothesis had been published in its German translation a year earlier, and was seminal in working out the new concept: the intention was to establish common ground (what one could call a mission statement of the institution) that was to emphasize the differences in taste, as well as in artistic and educational approach, of all the film educators involved. This entailed not only a translation of Bergala's understanding of the passeur into a practical environment, but also the expansion of the concept to a team of film educators. Film education at the KurzFilmSchule is not the task of one passeur, but is conducted by a team of up to three film-makers. Thus, film education is a process of negotiating in dialogue a socalled 'aesthetic argument' (Rolle et al., 2015 - the notion of 'aesthetic argument' was invented in the field of music pedagogy), aiming to come to an agreement with regard to choice, placement and approach - what Bergala calls the basic mental operations in any creative process (Bergala, 2016: 75). This aesthetic struggle thus becomes the centre of any creative decision from the recording of images and sounds up to the montage, and is guided by two complementary principles:

1. The assertion that the film-makers do not know 'more' than the students. This does not negate the hierarchical order of the schools that the film-makers visit. Neither does it try to act as if the film-makers have a completely different background and experience from the students. Rather, the pedagogical concept attempts to establish a different relationship towards the idea of knowledge about/on film. In contrast to an asymmetrical understanding of knowledge between teacher and student, the workshops of the KurzFilmSchule are based on an 'equality of intelligence' (Rancière, 1991: 45 and passim), as well as a mutual understanding that the outcome of the finished film cannot be predetermined. The film-makers are part of the joint endeavour of making a film, and repeatedly emphasize that they do not know how to make the film and are as curious about the result as the students. This entails that the form of these films are often experimental, and only marginally related to a professional film in a classical sense.

2. The film-makers articulate their own desire. They try to be involved in the process as far as possible; they do not try to take up a neutral position of teaching, explaining 
or counselling, but rather aim for a shared responsibility for the aesthetic decisions that have to be made during the production of a short film.

The conditions of practice in the context of the KurzFilmSchule outlined above thus lead to a form of film education that is not so much interested in the different materialities of film, as is the case in the Austrian Film Museum, but rather focuses on different forms of telling a story cinematically. The short film is an ideal format for this as it can function as a laboratory or testing ground for cinematic forms of representation and narrative. Gaining an understanding of film in the context of the KurzFilmSchule is not achieved only by the films themselves, however, but more importantly through the experience of an artistic working process. Again, this is based on the specific creative methods of each film-maker, which, as Bergala (2016: 22) points out, cannot fully be conveyed through written accounts but only through the creative act of making a film.

The unique taste and educational approach of each film-maker, as well as the experimental ways of seeing, thinking and telling stories in a short film, thus meet and productively rub against the viewing habits of students constantly in contact with the mainstream aesthetics perpetuated through cinema, television and computer games. Short films and the experimental artistic practice of the film-makers involved become relevant in an educational sense in that they irritate established experiences and expectations of what film is, and at the same time provide conditions of practice allowing for processes of learning to take place in the film-educational approach discussed above.

\section{Conclusion}

What has been discussed in this paper is first and foremost, we believe, a confirmation of the ideas and concepts that Alain Bergala brings together in The Cinema Hypothesis. The idea of the passeur and the concept of taste stand at the centre of Bergala's way of teaching cinema and have an influence on a variety of other choices and goals, ranging from the choice of films to the didactic approaches and expected outcomes of the educational processes. We have also attempted to expand these concepts through a shift of theoretical perspective that tries to integrate Bergala's idea of the passeur into a media-ecological approach. It is our assertion that the basic notion of the passeur, which is so central to Bergala's thinking, should be expanded in relation to the 'conditions of practice' of different contexts of film education. This leads us also to question Bergala's notion that film is an art and not a medium. While we understand this distinction in the context of the educational policy outlined in The Cinema Hypothesis we also perceive this to be somewhat reductive and lacking in complexity. It goes without saying that films do not only contain a specific aesthetic but also a specific materiality and media-related properties that must be thought of in relation to infrastructures and certain practices. In the context of this article, we have tried to focus on the influences and impact that the complex material, technological, medial, symbolic and social circumstances of institutions have on the idea of film education, and on the way that film is ultimately being taught.

These conditions of practice should not be thought of as a second level influencing the individual taste and abilities of the passeur. On the contrary, the idea is to understand taste and everything else that makes up a passeur as being already mediated by an infrastructure of perceptions, affect and actions of human and non-human actors. Institutions can be seen as one part of these infrastructures. The conditions of practice of a given institution thus shape what we perceive as an individual taste or a specific approach to teaching in terms of both limitations and 
affordances, and are thus central to understanding any given project of film education. Every description of a practical film-education initiative therefore always remains regional or situated (that is, limited) and at the same time precise (that is, detailed).

A media-ecological perspective of film education gives us the possibility to find and map these complex institutional, material, technological, mediated and social conditions of practice - be that in schools, at film clubs, on the internet or in film museums - and emphasizes their differences. Two case studies from our own educational practices have been outlined in such a manner: what has become clear is how differently the Austrian Film Museum and the KurzFilmSchule Hamburg go about teaching cinema - from the spaces they can make use of to the ways in which films are seen, from the question of who teaches and in which context to what the expected outcome might be - and how both still can be put into relation to Bergala's central ideas.

In conclusion, we suggest a focus on these different practices, and the prioritization of situated knowledge that creates specific theorizations without becoming a theory applicable across all contexts. This in turn implies two things: on the one hand, it means that one needs to distance oneself from larger, universal film-educational theories. On the other, it means focusing on a partial and situated knowledge, which can be discovered in any practice of film education with a degree of self-reflection. The question is then how far each of these regional theorizations are bound to their conditions of practice, and the extent to which they still carry within them a shared understanding of what film education wants and aims at. It is this last aspect that a broader implementation of film education in our educational system requires. The approach we discuss here suggests that, in order to get there, it might make sense to collect descriptions of existing projects and relate them to their specific contexts, and only then find out if a common nucleus is shared between them. At the same time, it is also possible that the media-ecological mapping of film-educational institutions and practices suggested here will reveal that there is hardly a common and shared understanding of what film is, or of how it can be taught. The two case studies, however, seem to suggest that there are common pillars even in film education practices as different as those of the Austrian Film Museum and the KurzFilmSchule Hamburg.

\section{Notes on the contributors}

Alejandro Bachmann studied film and American studies at the University of Mainz, Germany and the University of Wellington, New Zealand. He is Head of the Education, Research and Publications Department of the Austrian Film Museum, as well as an associate editor of Found Footage Magazine, and writes frequently for scholarly publications and magazines with a focus on film theory and education, documentary film and experimental cinema. He recently edited Spaces in Time: The films of Nikolaus Geyrhalter (Sonderzahl, 2015), co-edited nach dem Film No. 15: The Invisible Cinema (Department for Film studies at the University of Bremen and the Free University of Berlin, 2017) and is currently working on a book about the documentary films of Werner Herzog.

Manuel Zahn studied educational science, philosophy and psychology at the University of Hamburg and received his doctorate with a book on aesthetic film education. He is Professor of Aesthetic Education at the Institute for Art and Art Theory at the University of Cologne. He previously worked as Professor of Art Education at the Academy of Fine Arts Brunswick, and as a research assistant at the universities of Oldenburg and 
Hamburg. His fields of work are: philosophy of education; media pedagogy, especially film education; and arts education in digital media culture.

\section{References}

Bergala, A. (2016) The Cinema Hypothesis: Teaching cinema in the classroom and beyond (FilmmuseumSynemaPublikationen 28). Trans. Whittle, M. Vienna: Austrian Film Museum.

Grissemann, S., Horwath, A. and Schlagnitweit, R. (eds) (2010) Was ist Film: Peter Kubelkas Zyklisches Programm im Österreichischen Filmmuseum (FilmmuseumSynemaPublikationen 14). Vienna: Austrian Film Museum.

Haraway, D. (1988) 'Situated knowledges: The science question in feminism and the privilege of partial perspective'. Feminist Studies, 14 (3), 575-99.

Hörl, E. (ed.) (2011) Die technologische Bedingung: Beiträge zur Beschreibung der technischen Welt. Berlin: Suhrkamp.

Löffler, P. and Sprenger F. (eds) (2016) Medienökologien (Zeitschrift für Medienwissenschaft 14). Zürich: Diaphanes.

Rancière, J. (1991) The Ignorant Schoolmaster: Five lessons in intellectual emancipation. Trans. Ross, K. Stanford: Stanford University Press.

Richards, R.W. and Johnson, D.T. (eds) (2017) For the Love of Cinema: Teaching our passion in and outside the classroom. Bloomington: Indiana University Press.

Rolle, C., Knörzer, L. and Stark, R. (2015) 'Music-related aesthetic argumentation: Confronting a theoretical model with empirical data'. In Georgii-Hemming, E., Holgersen, S.-E., Varkøy, $\varnothing$. and Väkevä, L. (eds) Nordic Research in Music Education Yearbook (Vol. 16). Oslo: Norges musikkhøgskole, 315-26. 